BOGUMIŁA WARZĄCHOWSKA* - KATOWICE

\title{
BIBLIOTEKI KLASZTORNE NA ŁAMACH „NASZEJ PRZESZŁOŚCI”. ZARYS PROBLEMATYKI
}

Czasopismo Nasza Przeszłość. Studia z dziejów Kościoła i kultury katolickiej w Polsce, wydawane przez Instytut Wydawniczy Księży Misjonarzy, w 2006 r. obchodziło 60-lecie istnienia. Zostało powołane do życia 8 września $1946 \mathrm{r}$. w Krakowie przez ks. Alfonsa Schletza ${ }^{1}$. Ks. A. Schletz nie tylko stworzył podstawy „Naszej Przeszłości”, ale kierował periodykiem z prawdziwym uporem, jako wydawca, redaktor, adiustator, korektor, administrator i niemal kolporter, przez pełnych 35 lat, do 1981 r. Nasza Przeszłość od początku konsekwentnie realizowała program zarysowany przez ks. Redaktora we wstępie, w którym przyznaje, że „Wszystko zatem, co tylko ma związek z historią kultury katolickiej w Polsce, stanie się przedmiotem zainteresowań naszych i badań. Będziemy zamieszczać rozprawy z dziedziny historii Kościoła w Polsce, historii zakonów, historii teologii, dziejów pracy misyjnej w kraju naszym i za granicą; rozprawy ogólniejszej natury, teologiczne i filozoficzne, historyczno-prasowe, społeczne związane z kulturą polską, znajdą również miejsce na łamach naszego wydawnictwa" "2. Zaopatrzony w taki programowy wstęp redakcyjny, tom skromny, bez ilustracji czy map, wchodził jednak w świat nauki katolickiej. Nieśmiało rozgłoszony, potrzebujący silnego poparcia, przeniknął do gabinetów uczonych i dotarł do każdego zainteresowanego kościelną przeszłością naszej ojczyzny w jej wielorakim bogactwie.

Od 1949 do 1956 pismo przestało się ukazywać ze względów politycznych. Mimo wydanych zaledwie czterech tomów było dostrzeżone i odniosło duży sukces wydawniczy. Ks. Biskup Czesław Falkowski tak pisał m.in. do Redaktora Naszej Przeszłości: „Wydawane, bowiem w latach 1946-1948 pierwsze cztery tomy, zawierające szereg wartościowych prac i materiałów z dziejów Kościoła

* Bogumiła Warząchowska - mgr bibliotekoznawstwa i informacji naukowej, starszy kustosz dyplomowany, kierownik Biblioteki Teologicznej Uniwersytetu Śląskiego w Katowicach.

${ }^{1}$ B. Micewski, Schletz Alfons (1911-1981) misjonarz, redaktor $i$ wydawca, wyktadowca patrologii i historii Kościoła, w: Słownik Polskich Teologów Katolickich 1918-1981, t. 7, red. L. Grzebienia. Warszawa 1983, s. 86-99.

${ }^{2}$ A. Schletz, Od redakcji, „Nasza Przeszłość” (dalej: NP), 1 (1946) s. 4. 
i kultury katolickiej w Polsce, stanowią cenny i trwały dorobek naukowy. Spotkały się one z żywym uznaniem historyków i budziły zachętę do dalszych badań naukowych w tej ważnej dziedzinie"3. Po 9-letniej przerwie szczęśliwe okoliczności pozwoliły na wznowienie wydawnictwa. Z tej okazji do Redakcji wpłynęło wiele listów gratulacyjnych m.in. od Prymasa Polski, ks. Stefana Wyszyńskiego oraz Arcybiskupa Krakowa ks. Eugeniusza Baziaka z zachętą do dalszej niestrudzonej pracy ${ }^{4}$. W 1957 roku w piątym tomie wznowionego czasopisma ks. A. Schletz informował, że „Unikać będziemy w naszym piśmie tego wszystkiego, co bezpośrednio dotykać będzie współczesności. Nie obce nam jednak będą sprawy odnoszące się nie tylko do dalekiej, ale i bliskiej przeszłości, zwłaszcza w zakresie biografii i hagiografii. Program, jaki Redakcja zakreśliła sobie we wstępie do pierwszego tomu, nadal jest aktualny. Nasza Przeszłość zawsze jeszcze czeka na współpracowników i autorów rozpraw z dziedziny historii polskiej myśli katolickiej i społecznej roli Kościoła w naszej Ojczyźnie. Redakcja otwiera gościnne łamy dla autorów, myślących i piszących po katolicku, którym historia i kultura katolicka w naszym kraju jest bliską i drogą" 5 . Charakter czasopisma po przerwie uległ zmianie - nie tyle programowej, ale faktycznej. Dawne pokolenie historyków Kościoła drukowało coraz mniej, chociaż wielokrotnie swoim autorytetem wspierało pismo. Pojawili się natomiast ludzie młodzi zarówno duchowni, jak i świeccy bez obciążeń i uprzedzeń. Ich prace spowodowały zmianę oblicza czasopisma, wypełnionego teraz przeważnie obszernymi tekstami o charakterze materiałowym i źródłowym. Redaktor naczelny, jak i jego współpracownicy, a zwłaszcza autorzy artykułów, publikowali takie materiały z przeszłości, które nie budziły sprzeciwu ówczesnej władzy. Dzięki tej dużej roztropności i ostrożności zespołu redakcyjnego, czasopismo ukazuje się już nieprzerwanie od $1957 \mathrm{r}$.

W roku 1971 Redakcja Naszej Przeszłości obchodziła jubileusz 25. lecia pracy wydawniczej. Listy gratulacyjne adresowane do ks. Redaktora z okazji srebrnego jubileuszu pisma są dowodem uznania dla tego typu pracy. Po dwudziestu pięciu latach tak mówił o periodyku Prymas Stefan Wyszyński: „Wydobywać umiejętnie z przeszłości wszystko, co miało miejsce w dziejach Kościoła Katolickiego, działającego w Polsce - jest sztuką niełatwą. Pracy Kościoła nie można bowiem oceniać tylko z faktów historycznych, środowiska czasów i ludzi, w których była prowadzona. Dzieje Kościoła są zawsze syntezą działania Boga wśród ludzi i przez ludzi, działania w porządku natury i łaski, działania na niwie pszenicy i kąkolu, świętości i słabości, porywów dobrej woli i ludzkich niedomagan"”. Takiemu dziełu służyła i służy Nasza Przeszłość. Jej zadanie polega na odkrywaniu w przeszłości tego, co pomoże kształtować życie współczesnych pokoleń.

${ }^{3}$ List J. Eksc. Ks. Biskupa Czesława Falkowskiego do Redaktora „Naszej Przeszłości”, NP, 5 (1957) s. 6.

${ }^{4}$ Stowo J. Em. Ks. Kardynata Stefana Wyszyńskiego, Prymasa Polski do Redakcji „Naszej Przeszłości”, NP, 5 (1957) s. 4; J.Eksc. Ks. Arcybiskup Eugeniusz Baziak do Redakcji „,Naszej Przeszłości”, NP, 5 (1957) s. 5.

${ }^{5}$ A. Schletz, Po dziewięciu latach, NP, 5 (1957) s. 3.

${ }^{6}$ List gratulacyjny Prymasa Polski z dn. 19 czerwca 1971 roku z okazji Srebrnego Jubileuszu. „Nasza Przeszłośc”, NP, 36 (1971) s. 7. 
Nie bez wpływu na rozwój czasopisma był fakt, że powstało ono w Krakowie, o czym tak jednoznacznie pisał Kardynał Karol Wojtyła w kolejnym liście gratulacyjnym: „Kraków jest jakimś szczególnym warsztatem dla historyków, wszystko tu mówi o naszej przeszłości i wszystko zachęca do podejmowania zagadnień z historii Kościoła"7. Podsumowując treści wielu listów gratulacyjnych należy stwierdzić, że w ciągu ubiegłego dwudziestopięciolecia ukazało się na łamach Naszej Przeszłości dużo interesujących prac monograficznych, rozpraw, artykułów i recenzji obejmujących szeroki wachlarz zagadnień i problemów, które wywarły poważny wpływ na rozwój dziejów Kościoła w Polsce.

Od 1946 r. do chwili obecnej ukazało się 113 tomów. Od pierwszego numeru rokrocznie wychodzą dwa obszerne tomy liczące ok. 300 stron druku. Również format A5 czasopisma nie uległ zmianie. Na stronie tytułowej umieszczony jest tytuł i podtytuł, nazwisko redaktora, numer zeszytu, rok i miejsce wydania. Od tomu siódmego równolegle do strony tytułowej w języku polskim jest strona tytułowa w języku francuskim. Po pół wieku ukazywania się „Naszej Przeszłości”, o początkach czasopisma i jego szacie tak pisał biskup Jan Kopiec „Według dzisiejszych miar tom skromny, jakość papieru nie wywołująca zachwytu, bez ilustracji czy map"8. Dopiero w latach osiemdziesiątych zaczęto ubogacać artykuły ilustracjami. Również na okładce pojawia się regularnie od tomu 70 fotografia obiektów sakralnych. Na końcu każdego tomu znajduje się spis treści oraz wykaz książek nadesłanych do redakcji. Patrząc na regularne ukazywanie się pisma oraz dobry poziom artykułów należy przyznać, że „pismo miało dotąd szczęście do redaktorów. Dzieło życia ks. prof. Alfonsa Szletza, który zdołał wydać 55 tomów, przejął i wydał 3 tomy ks. dr Tadeusz Gocłowski, a od 59 do setnego tomu włącznie kontynuował ks. dr Jan Dukała, zapisując się tym samym trwale w dziejach nie tylko samego pisma, ale również polskiej nauki kościelno-historycznej”"

\section{Problematyka Naszej Przeszłości}

Na łamach „Naszej Przeszłości” zamieszczano teksty, w których przeważają zagadnienia historii Kościoła w Średniowieczu - epoki szczególnie uprzywilejowanej przez historyków Kościoła. Natomiast w okresie staropolskim oparto się głównie na analizie materiałów źródłowych penetrując głównie zbiory i archiwa klasztorne, ze szczególnym naciskiem na wiek XVII i XIX. Słabo prezentowane są natomiast materiały dotyczące czasu Reformacji, Oświecenia osiemnastowiecznego i wieku XX. Redakcja czyni jednak widoczne starania o to by omówić dzieje Kościoła nie wszystkich historycznych regionach Polski. Dość często re-

${ }^{7}$ List gratulacyjny Kardynała Wojtyly z dn. 27 maja 1971 roku z okazji Srebrnego Jubileuszu, NP, 36 (1971) s. 8.

8 J. Kopiec, Pół wieku „, Naszej Przeszłości”, NP, 87 (1997) s. 421.

9 J. Strzelczyk, Sto tomów ,Naszej Przeszłości”. Tło, struktura, linie rozwoju, tendencje, w: Sto tomów „Naszej Przeszłości”. Bibliografia, dzieje, ludzie, red. J. Dukała, J. Kopiec, Kraków 2003, s. 428 . 
prezentowana jest problematyka galicyjska oraz Królestwa Polskiego. Rzadziej omawia się natomiast dzieje regionu w Wielkopolsce, na Śląsku i na Pomorzu.

Badania w zakresie historii Kościoła katolickiego w Polsce, przed pojawieniem się na rynku wydawniczym Naszej Przeszłości były znaczące, „były jednak rozproszone, przemieszane z zagadnieniami teologicznymi, publikowane w różnych organach naukowych. Chodziło więc o koordynowanie tych badań, ewentualnie stworzenie środowiska uczonych historyków, zajmujących się tematyką dziejów Kościoła i kultury, następnie publikacje prac w czasopiśmie o wyraźnym profilu wydawniczym"10.

Pod względem tematycznym w „Naszej Przeszłości” dominują cztery działy:

1. Zagadnienia ogólne oraz społeczno-polityczno-ustrojowe warunki działalności Kościoła

2. Życie religijne wraz z liturgią, duszpasterstwem i kultem świętych, ewentualnie również z nauczaniem i szkolnictwem,

3. Dzieje zakonów i zgromadzeń religijnych,

4. Dzieje sztuki kościelnej, zwłaszcza architektury sakralnej ${ }^{11}$.

Trzon każdego tomu stanowią rozprawy wybitnych uczonych oraz początkujących pracowników nauki w wymienionych dziedzinach. „Na łamach „Naszej Przeszłości przewinęły się setki nazwisk uczonych duchownych i świeckich. Wśród nich odnajdujemy całą plejadę nazwisk pierwszorzędnych, współdecydujących o dziejach polskiej nauki historycznej.[...] Redakcja Naszej Przeszłości śmiało wychodziła poza krąg luminarzy, udostępniając łamy autorom mniej znanym,[...]którzy prawdopodobnie nie zdołaliby się przebić do druku gdzie indziej" ${ }^{2}$. Artykuły zamieszczone w tym piśmie są poważnym dorobkiem naukowym piszących.

Szereg tomów zawiera również dział „Miscellanea” z drobnymi przyczynkami, informacjami i materiałami historycznymi publikowane są biografie historyków i działaczy kościelnych, opatrzone niezwykle bogatym zestawieniem bibliografii podmiotowych. Prowadzony dział recenzji, sprawozdań, kroniki i nadesłanych książek ułatwia natomiast orientację w minionych wydarzeniach i bieżącej literaturze przedmiotu. Zamieszczanie polemik między autorami a recenzentami świadczy o tym, że Redakcja dopuszcza pluralizm poglądów i pozostawia piszącym swobodę wypowiedzi. Godne uznania jest również dążenie pisma do wyposażenia artykułów w liczne ilustracje, fotografie i mapy, które ułatwiają lekturę i mają znaczenie dokumentów źródłowych.

${ }^{10}$ J. Kopiec, „Nasza Przeszłość” w stużbie nauki, kultury i Kościoła w Polsce, w: Sto tomów „Naszej Przeszłości”, s. 273.

${ }^{11}$ J. Strzelczyk, „Nasza Przeszłość” - znaczenie w nauce historycznej, NP, 87 (1997) s. 448.

${ }^{12}$ Tenże, Sto tomów „Naszej Przeszłości”. Tło, struktura, linie rozwoju, tendencje, w: Sto tomów „, Naszej Przeszłości”, s. 430. 


\section{Zagadnienie książek i bibliotek klasztornych na łamach Naszej Przeszłości}

Analizując zawartość treściową Naszej Przeszłości można zauważyć, że na jej łamach znajduje się pokaźna część artykułów dotyczących zgromadzeń zakonnych i życia monastycznego. Bibliografia zawartości pierwszych 70 tomów $\mathrm{Na}$ szej Przeszłości do 1988 r. zestawiona starannie przez Stanisława Srokę w tomie 75 z 1991 r. ogromnie ułatwia orientację w bogactwie treści periodyku. Pozostałe 43 tomy, nie objęte jeszcze opracowaniem bibliograficznym, być może doczeka się zbiorczego uporządkowania.

Mimo, że dział „Zakony i zgromadzenia zakonne” jest bogato reprezentowany w Naszej Przeszłości to jednak materiałów dotyczących bibliotek klasztornych opracowanych samoistnie jest niewiele. Należało prześledzić historię wielu zakonów, wczytać się w treść opracowań, ażeby dotrzeć do szczątkowych informacji mówiących o istnieniu biblioteki w danym klasztorze. W literaturze źródłowej potwierdzają się informacje, że „władze zakonne nie pozwalały na zakładanie klasztorów bez lektora tj. osoby dokształcającej zakonników w teologii. Z tego więc względu, a także dla ułatwienia pracy duszpasterskiej, każdy konwent posiadał chociażby małą podstawową bibliotekę. Większe klasztory szczyciły się bogatymi księgozbiorami”'13. W tekstach ogłaszanych na łamach „Naszej Przeszłości” często porusza się problemy dotyczące struktury organizacyjnej klasztoru, życia zakonnego i spraw codziennych, problematyka książek i bibliotek klasztornych ujmowana jest jedynie marginalnie.

Pierwsze wzmianki o bibliotece klasztornej znajdujemy dopiero w 16 tomie Naszej Przeszłości z roku 1962. Sławomira Pełeszowa w materiale „Dar Mikołaja Tryzny dla Biblioteki Bazylianów w Byteniu” pisze „Rejestr ksiąg przekazanych Zakonowi Bazylianów w Byteniu w r. 1640, nie jest spisem zawartości całego księgozbioru Mikołaja Tryzny, obejmuje on bowiem dzieła, w zasadzie, tylko o charakterze teologicznym" ${ }^{14}$. Spis ten nie budzi specjalnego zainteresowania, mimo to godzien jest odnotowania, jako jeden z zabytków kultury religijnej na kresach północno-wschodnich Rzeczypospolitej w I poł. XVII w. Religijna tematyka ksiąg jest niewątpliwie wyrazem pobożności ludzi dawnych wieków i aktualnych wówczas problemów. Gromadzony księgozbiór rzuca również światło na osobiste zainteresowania umysłowe i religijne podskarbiego i jego środowiska. Spis ksiąg jest także źródłem do badań dziejów biblioteki nowo ufundowanego wtedy klasztoru byteńskiego, jak również i z tego tytułu zasługuje na uwagę. Szkoda tylko, że brak jest wiadomości o dziejach gromadzenia księgozbioru przez Mikołaja Tryznę i że nie ma wzmianki o bibliotece obdarowanego klasztoru. Również życiorys podskarbiego nie przybliża tych spraw, ponieważ materiały biograficzne są nader skąpe.

${ }^{13}$ J. Kłoczowski, Zakony na ziemiach polskich $w$ wiekach średnich, w: Kościót w Polsce, t. 1, Kraków 1966, s. 548.

14 S. Pełeszowa, Dar Mikołaja Tryzny dla Biblioteki Bazylianów w Byteniu, NP, 16 (1962) s. 239 . 
Po dziesięciu latach tj. w 1973 r. doczekaliśmy się w Naszej Przeszłości obszernego opracowania dotyczącego dawnych klasztornych bibliotek dominikanów w polskich prowincjach. Cały rocznik 39 poświęcony został działalności zakonów dominikańskich w Polsce, architekturze dominikańskiej, a zawdzięczamy te opracowania 750. rocznicy założenia prowincji polskiej. O tym, czy materiał odnoszący się do bibliotek dominikanów został rzetelnie przeanalizowany, możemy dowiedzieć się z artykułu Krystyny Zawadzkiej, którego tytuł brzmi „Ze źródeł i stanu badań dotyczących dawnych klasztornych bibliotek dominikanów w Polskich Prowincjach". Materiał w nim zebrany wykazuje bogate źródła w postaci inwentarzy, katalogów i resztek dawnych księgozbiorów, a także fragmentaryczne wzmianki w literaturze o dominikańskich bibliotekach ${ }^{15}$. Niełatwo jest odnaleźć książki należące kiedyś do tych bibliotek. Zostały one, bowiem po kasacie klasztorów dominikańskich rozproszone po bibliotekach państw zaborczych, a część już z nich wcześniej została wywieziona do Szwecji ${ }^{16}$. Niektóre księgozbiory zostały włączone do polskich bibliotek uniwersyteckich, książnic towarzystw naukowych, seminariów duchownych i zbiorów prywatnych ${ }^{17}$. Być może dokładniejsze przebadanie archiwum i biblioteki dominikanów w Krakowie, a także katalogów, względnie zbiorów innych bibliotek, ujawniłoby więcej źródeł odnoszących się do księgozbiorów dominikańskich. Badając biblioteki dominikańskie, K. Zawadzka zestawiła je w czterech grupach zależnie od rodzaju materiału świadczącego o istnieniu księgozbiorów:

1. Biblioteki posiadające inwentarze (katalogi), część książek i wzmianki w literaturze;

2. Biblioteki posiadające inwentarze (katalogi) i ewentualnie wzmianki w literaturze;

3. Biblioteki posiadające książki i ewentualnie wzmianki w literaturze;

4. Biblioteki posiadające wzmianki w literaturze:

Dla pełniejszego obrazu bibliotek dominikańskich zostaną jeszcze wymienione te, o których istnieniu można wnioskować na podstawie zwyczajów dominikańskich. Jak wiadomo dominikanie byli tym zgromadzeniem, które nie zakładało swych klasztorów bez lektora, a jego obecność w konwencie świadczyła o egzystującej tam bibliotece ${ }^{18}$. Niezależnie od materiału zgromadzonego w artykule, K. Zawadzkiej, konieczne są poszukiwania po wspomnianych wyżej bibliotekach i wgląd w ich katalogi, inwentarze i materiały archiwalne w celu zidentyfikowania gromadzonych książek. Duże znaczenie dla badaczy bibliotek klasztornych ma zamieszczona literatura przedmiotu, która ułatwi znalezienie źródeł bibliotecznych, uzupełni je, a czasem sama stanie się źródłem.

${ }^{15} \mathrm{~K}$. Zawadzka, Ze źródet $i$ stanu badań dotyczacych dawnych klasztornych bibliotek dominikanów w Polskich Prowincjach, NP, 39 (1973) s. 214.

${ }^{16}$ S. Ptaszycki, Encyklopedia nauk pomocniczych historii i literatury polskiej, Lublin 1921, s. 75.

${ }^{17}$ A. Kawecka-Gryczowa, Katalog inkunabułów Biblioteki Zakt. Nar. Im. Ossolińskich we Wrocławiu, Wrocław 1956, s.76.

${ }^{18} \mathrm{~K}$. Zawadzka, Ze źródet i stanu badań dotyczacych dawnych klasztornych bibliotek dominikanów w Polskich Prowincjach, NP, 39 (1973) s. 226. 
Po tak bogatym i obszernym materiale źródłowym dotyczącym dominikanów przez wiele lat nie odnotowano prac mówiących o bibliotekach klasztornych, chociaż o samych zgromadzeniach pisano wielokrotnie.

Materiały dotyczące likwidacji klasztoru franciszkanów w Lelowie dają skromne informacje na temat istniejącej tam biblioteki. Upadek klasztoru franciszkanów w Lelowie, przypisywano zubożeniu konwentu na skutek zmniejszenia się ofiarności ludu i braku zakonników do obsadzania nimi koniecznych etatów w klasztorze. Po śmierci ostatniego gwardiana dokonano spisu inwentarza pofranciszkańskiej własności. Na wniosek komisji uznano, że „kościoły parafialne nie dosyć w aparaty zamożne, obdzielić aparatami pofranciszkańskimi, książki odesłać do Warszawy na publiczny użytek, albo drogą licytacji spieniężyć. Jednocześnie przesłany został spis książek" ${ }^{19}$. Ostatecznie nie wiadomo jaki los spotkał bibliotekę lelowskich franciszkanów i ile z posiadanych przez nich książek, zgodnie ze spisem dotarło do Warszawy.

O tym, że kapucyni lubelscy posiadali bibliotekę dowiadujemy się w nietypowych okolicznościach. Bowiem, klasztor ojców kapucynów w Lublinie był wielokrotnie wykorzystywany w celu przyjęcia demerytów ${ }^{20}$ diecezjalnych i służył roztoczeniu nad nimi opieki duchowej. Podobnie jak w innych domach demeryckich skazani duchowni przebywający pod nadzorem kapucynów lubelskich podporządkowani byli przepisom o pracy umysłowej czytali więc książki teologiczne, zagłębiali się w literaturze ascetycznej, korzystali także z czasopism biblioteki klasztornej ${ }^{21}$. Analiza czytelnictwa demerytów daje wyobrażenie o strukturze księgozbioru biblioteki kapucynów.

I znowu nam przyjdzie czekać kolejne dziesięć lat zanim na łamach „Naszej Przeszłości" pojawi się informacja o bibliotekach klasztornych. Tym razem charakteryzując działalność księży misjonarzy prowincji krakowskiej natrafiamy na wzmianki o ich bibliotekach. W swojej bogatej i różnorodnej pracy, misjonarze zajmowali się działalnością wydawniczą. Charakterystyka i ocena dorobku wydawniczego misjonarzy prowincji krakowskiej jest bardzo trudna, bowiem brak jakichkolwiek materiałów archiwalnych i katalogów wydawniczych, z których zachował się tylko jeden, pochodzący sprzed wybuchu I wojny, obejmujący 88 pozycji. Na szczęście biblioteki misjonarskie w Krakowie na Stradomiu i Kleparzu dysponują wieloma pozycjami wydawniczymi zgromadzenia i na tej podstawie można pokusić się o pewną dość ogólną prezentację tego dorobku ${ }^{22}$. Z materiałów archiwalnych wynika, że wszystko to co publikowali księża misjonarze było gromadzone w ich zbiorach bibliotecznych. Książki i broszury wydawane nakładem misjonarzy można zasadniczo podzielić na dwie grupy. Do pierwszej z nich, należy zaliczyć pozycje przeznaczone wyłącznie dla misjonarzy i sióstr

${ }^{19}$ Z. Zaborski, OO. Franciszkanie w Lelowie, NP, 66 (1986) s. 27.

${ }^{20}$ Demeryci, to duchowni skazani za różne przewinienia na pobyt w domu pokuty w celu zadośćuczynienia i poprawy.

${ }^{21}$ M. Budziarek, Udział kapucynów w życiu religijnym Lublina i lubelszczyzny w XIX w., NP, 66 (1986) s. 199.

${ }^{22}$ S. Janaczek, Działalność Księży Misjonarzy Prowincji Krakowskiej 1865-1914, NP, 77 (1992) s. 221 . 
miłosierdzia, a więc różne wydania reguł, zwyczajników, rozmyślań, listów generałów i wizytatorów, teksty litanii do użytku wewnętrznego oraz konferencje św. Wincentego przeznaczone dla obu rodzin wincentyńskich. Na drugą grupę składają się druki publikowane z myślą o czytelnikach z zewnątrz, i to zarówno duchownych, jak i świeckich. Publikacje te cechuje duża różnorodność, są przedruki, tłumaczenia i teksty napisane oryginalnie. Najobszerniejszy dział stanowią broszury popularno-dewocyjne oraz różnego rodzaju zbiory modlitw. Wydawano je masowo, zwłaszcza od lat osiemdziesiątych XIX w. rozpowszechniano, wśród uczestników kleparskich rekolekcji zamkniętych oraz w czasie misji ${ }^{23}$. Mówiąc o gromadzonych książkach i broszurach trzeba również wspomnieć o wydawanych i gromadzonych przez księży misjonarzy czasopismach. ${ }^{24}$ Najważniejszym z nich były: Roczniki Obydwóch Zgromadzeń św. Wincentego a Paulo, Roczniki Dzieta św. Dziecięctwa Pana Jezusa oraz Miłosierdzie Chrześcijańskie. Z przeprowadzonych badań i zaobserwowanych faktów wynika, że do oddziaływania słowem drukowanym przywiązywali księża misjonarze sporą wagę i czynili starania, by podnosić poziom duchowy swoich wydawnictw.

Wnikliwego i wartościowego opracowania na podstawie zgromadzonych źródeł doczekała się Biblioteka Księży Misjonarzy u św. Krzyża w Warszawie. Jest ona jedną z największych i najważniejszych bibliotek okresu Oświecenia w Warszawie. Zachowała się wyjątkowo bogata, jak na zdewastowane księgozbiory warszawskie dokumentacja tej biblioteki, obejmująca archiwalia i podstawowy zasób książek z tej kolekcji ${ }^{25}$. Najważniejsze źródła do dziejów Warszawskiej Biblioteki Misjonarskiej znajdują się w Archiwum Archidiecezjalnym Warszawskim i w Archiwum Księży Misjonarzy przy wspomnianej wcześniej Bibliotece w Krakowie na Stradomiu. W Archiwum Archidiecezjalnym Warszawskim poza bogatym materiałem źródłowym dotyczącym księgozbioru przechowywane są inne cenne archiwalia. Wśród nich najbardziej interesujący jest katalog połączony z księgą wypożyczeń, pochodzący prawdopodobnie z pierwszej połowy XVIII w. Innym ciekawym dokumentem, który można nazwać księgą akcesyjną, jest księga spisana na odwrocie innego dokumentu, zawierająca siedem spisów książek. Również Archiwum Naszej Przeszłości w Krakowie posiada kilka zbiorów rękopiśmiennych dokumentów dotyczących dziejów misjonarzy, oraz w osobnych materiałach uwagi na temat Biblioteki Domu Warszawskiego. To tylko nieliczne źródła, na których ks. Krzysztof Gonet oparł swoje opracowanie dotyczące biblioteki księży misjonarzy u św. Krzyża w Warszawie.

Bogaty materiał źródłowy ilustrujący życie monastyczne w średniowieczu zebrał i zanalizował w 89 tomie Naszej Przeszłości Marek Derwich w artykule Stan i potrzeba badań nad wspólnotami monastycznymi w Polsce średniowiecznej. Jeden z podrozdziałów tekstu dotyczy badań nad kulturą monastyczną ${ }^{26}$. Opracowa-

${ }^{23}$ Tamże. s. 222.

${ }^{24}$ Tamże. s. 226.

${ }^{25}$ K. Gonet, Biblioteka księży misjonarzy u św. Krzyża w Warszawie. Zarys problematyki, NP, 86 (1996) s. 76.

${ }^{26}$ M. Derwich, Stan i potrzeba badań nad wspólnotami monastycznymi w Polsce średniowiecz$n e j, \mathrm{NP}, 89$ (1998) s. 32-40. 
nie to w dużej mierze dotyczy całego spektrum bibliotek klasztornych okresu średniowiecza. Wspomina się biblioteki benedyktynów, przedstawia monografię bibliotek cysterskich oraz kanoników regularnych, jak również opracowania poświęcone kartuzom. Uwadze badaczy, których teksty przeanalizował M. Derwich, nie uszły też aspekty pracy skryptoriów klasztornych, które na ówczesne czasy funkcjonowały w nieodłącznej symbiozie z bibliotekami. Podkreślono ich rolę zwłaszcza skryptoriów cysterskich i benedyktyńskich - w rozwoju iluminatorstwa książkowego. To niespotykane dotychczas przedstawienie literatury na temat klasztornych bibliotek średniowiecznych może, a na pewno powinno zachęcać bibliotekarzy, archiwistów, a zwłaszcza historyków Kościoła, do szczegółowego opracowania dziejów księgozbiorów poszczególnych bibliotek.

O losach kolejnych bibliotek klasztornych opisanych na łamach „Naszej Przeszłości” dowiadujemy się z tekstu Janusza Nowaka opisującego penetrację antykwariuszy, bibliotekarzy bądź prywatnych właścicieli bibliotek, uszczuplających stan posiadana klasztornych zbiorów ${ }^{27}$. Sztuka uszczuplania kościelnych i klasztornych zbiorów bibliotecznych z początku XIX w została udoskonalona po Powstaniu Listopadowym we wszystkich trzech zaborach. Termin ksiażkołap doskonały stosowano na określenie miłośników książek w tym i sławnych bibliotekarzy polskich z przełomu XVIII i XIX w., którzy pracowali dla właścicieli prywatnych zbiorów. Na ówczesne czasy potężne kolekcji posiadali: Andrzej Stanisław i Józef Andrzej Załuscy, Tadeusz Czacki, Samuel Bogumił Linde, Michał Juszyński, Józef Maksymilian Ossoliński i wielu innych, którzy wzbogacając swe zbiory, pomniejszali zasoby bibliotek klasztornych. Przedmiotem analizy wspomnianego opracowania Janusza Nowaka nie są dzieje ksiażkołapstwa lecz praca miłośników ksiąg, ich erudycja i wiedza na temat zawartości bibliotek klasztornych, a jednocześnie przechwytywanie zbiorów z tych bibliotek, o których do tej pory nie wspomniano w żadnym materiale źródłowym.

S. Małgorzata Borkowska często publikuje na łamach „Naszej Przeszłości”, specjalizując się w opracowaniach dziejów klasztorów żeńskich. Na uwagę zasługują zwłaszcza dwie prace a mianowicie Miscellanea Brygitańskie: Grodno ${ }^{28}$ oraz Miscellanea Brygitańskie: Warszawa, Luck ${ }^{29}$. Klasztor brygidek w Grodnie był obiektem wielokrotnie wznawianych badań historycznych tym bardziej, że posiadał zasobne archiwum utrzymane w należytym porządku. Dzięki przeprowadzonym badaniom dowiadujemy się, że ,biblioteka brygidek w Grodnie w $1848 \mathrm{r}$. liczyła 150 tomów, że wszystkie książki były po polsku, wydane w XVII i XVIII w. i że klasztor nie miał ekslibrisu, tylko zastępującą go notkę oraz o tym, że sporo jest książek pochodzących z klasztoru łuckiego, przywiezionych po jego kasa-

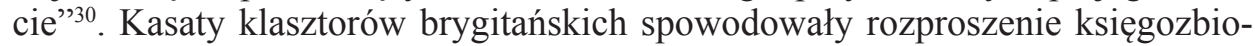
rów, wobec czego zawartość bibliotek nie jest do odtworzenia. Te fragmenty brygitańskich bibliotek, które tu i ówdzie zachowały się, świadczą, że tak jak w in-

${ }^{27}$ J. Nowak, Erwin Redel antykwariusz przeworski i jego penetracje bibliotek klasztornych 1871-1876. Przyczynek do dziejów , książkołapstwa” w Galicji, NP, 88 (1997) s. 329-353.

${ }^{28}$ M. Borkowska, Miscellanea Brygitańskie: Grodno, NP, 85 (1996) s. 137-158.

${ }^{29}$ Taż, Miscellanea Brygitańskie: Warszawa, Luck, NP, 87 (1997) s. 251-265.

${ }^{30}$ Taż, Miscellanea Brygitańskie: Grodno, NP, 85 (1996) s. 145. 
nych zakonach i tu kupowano książki różnorodne nie ograniczając się tylko do tekstów służących rozwojowi duchowości czy rodziny zakonnej. Jednak podstawowym dziełem, które w tym zakonie czytano, były objawienia Św. Brygidy, „Nadto zakon przyznawał się do kanonicznej, augustiańskiej tradycji duchowej, toteż można sądzić, że Wyznania św. Augustyna, choć niekoniecznie jego dzieła teologiczne, były brygidkom znane" ${ }^{31}$. Zarówno materiały archiwalne, jak i rozproszone księgozbiory brygidek, nie dają jednak całkowitego obrazu charakteru i wielkości bibliotek brygitańskich.

Jolanta Marszalka badając zachowane kroniki klasztorne a także inwentarze dóbr opactwa oo. Cystersów w Szczyrzycu, jedynego klasztoru cysterskiego w historycznych granicach Rzeczypospolitej, które nie uległo kasacie, stwierdziła, że „zarówno zbiory archiwum jak też biblioteka klasztorna nie zostały wywiezione do Rosji” ${ }^{32}$. Ponadto w zachowanym do dzisiaj archiwum klasztornym „obok najstarszych dokumentów pergaminowych, książęcych i królewskich przywilejów zatwierdzających liczne darowizny na rzecz klasztoru, zachowały się cenne kopiarze dokumentów, które po części spełniają role kronik, a także inwentarze majątku ruchomego i nieruchomego klasztoru oraz kościoła szczyrzyckiego"33. W archiwum tym znajduje się również zespół akt odnoszący się do Zakonu Kanoników Regularnych Laterańskich Bożego Ciała w Krakowie, z podpisami Marcina Kłoczyńskiego wytrawnego bibliofila zakonnego ${ }^{34}$. O tym, że zgromadzenie w Szczyrzycu miało zasobne zbiory archiwalne i biblioteczne świadczy również fakt, że w opactwie tym był zatrudniony archiwista i bibliotekarz klasztorny, co nie zawsze miało miejsce $w$ zakonach.

Opactwo z podkrakowskiej Mogiły było jednym z największych klasztorów cysterskich na ziemiach polskich, nic więc dziwnego, że XVIII wieku sprawowało mecenat nad nauką i sztuką, skupiając w swoich murach licznych uczonych ze stołecznego Krakowa. Klasztor, jako ważny ośrodek kultury umysłowej szczycił się także cennym zbiorem bibliotecznym. „Odnaleźć można zatem w klasztornym archiwum wiele cennych rękopisów i starodruków zachowanych z dawnych kolekcji, pośród których znajduje się bogaty zbiór osiemnastowiecznych muzykaliów"35. Kultura artystyczna i umysłowa cystersów mogilskich znalazła wyraz w tradycjach bibliofilskich, czego świadectwem są zachowane zabytki liturgiczno-muzyczne, obejmujące zarówno przykłady repertuaru sakralnego jak i kompozycje świeckie. Kolekcja mogilskich muzykaliów mimo upływu lat nie doczekała się szczegółowego opracowania i nadal jest otwarta na analizę uczonych muzykologów.

${ }^{31}$ Tamże, s.152.

${ }^{32}$ J. M. Marszalska, Najważniejsze źródła rękopiśmienne do dziejów klasztoru oo. Cystersów w Szczyrzycu, NP, 104 (2005) s. 40.

${ }^{33}$ Tamże: s. 38.

${ }^{34}$ J. M. Marszalska, Źródła do badań nad dziejami klasztoru Kanoników Regularnych Bożego Ciała w Krakowie w zbiorach archiwum oo. Cystersów w Szczyrzycu, NP, 108 (2007) s. 372.

${ }^{35}$ P. Szywalski, Osiemnastowieczne zbiory muzyczne archiwum klasztoru mogilskiego (kontekst historyczny), NP, 112 (2009) s. 238. 
Boruny to miejscowość na wileńszczyźnie, która zawdzięcza sławę m.in. placówce oświatowej prowadzonej przez bazylianów ${ }^{36}$ oraz jej absolwentom, wśród których znalazło się wielu zasłużonych dla nauki i kultury polskiej ${ }^{37}$. Na ówczesne czasy członkowie zakonu bazyliańskiego stanowili elity społeczne i intelektualne Kościoła unickiego, kładąc ogromne zasługi w prowadzeniu zasłużonej placówki oświatowej. W procesie edukacyjnym zgromadzenia znaczną rolę odgrywała biblioteka, której księgozbiór przy boruńskim klasztorze początkowo liczył ponad 800 woluminów, a po kilkunastu latach zasób powiększył się do 1390 woluminów w językach polskim, rosyjskim, łacińskim i włoskim ${ }^{38}$. Wśród zgromadzonych druków były księgi Pisma św. w języku łacińskim i polskim, dokumenty normatywne Cerkwi unickiej i Kościoła rzymskokatolickiego, dzieła teologiczne, utwory antyczne oraz podręczniki do nauki języków obcych, a zwłaszcza słowniki dwu i wielojęzyczne. Podręczniki i znaczna część literatury były dobierane przy współudziale środowiska naukowego Wilna, dzięki któremu „bogaty zasób biblioteki stanowił doskonałą bazę do studiów o różnorodnej tematyce"39.

Z kolei na ziemi przemyskiej w Ławrowie znajdował się najstarszy i największy męski klasztor reguły św. Bazylego Wielkiego z wpływami lwowskiego środowiska naukowego. Najważniejsze dziedziny aktywności zakonu bazyliańskiego w XVIII w. stanowiło duszpasterstwo i działalność wychowawczo-oświatowa. Pomocą w pracy edukacyjnej w monastyrze służyła biblioteka. „Była to najliczniejsza książnica bazyliańska na terenie eparchii przemyskiej i jedna z większych wśród monastyrów prowincji Opieki NMP" ${ }^{40}$, która słynęła z rzadkich rękopisów cerkiewno-słowiańskich oraz cennych dokumentów pergaminowych poświadczające przywileje otrzymane przez klasztor. O zasobie biblioteki klasztornej świadczyły dwa znaczące katalogi, a także 366 tytułów w 474 to$\mathrm{mach}^{41}$. Księgozbiór biblioteczny rozrastał się tak, że w XIX wieku liczył około tysiąc tomów, a „znaczną grupę ksiąg stanowiły cyrylickie dzieła teologiczne, pisma Ojców Kościoła chrześcijańskiego (tzw. pisma patrystyczne), dawne kroniki (latopisy) i liczne księgi liturgiczne Kościoła wschodniego. W bibliotece zgromadzono egzemplarze Pisma Św. oraz komentarze do tekstów biblijnych, dzieła religijne dotyczace teologii moralnej i dogmatycznej, filozofii, prawa, zbiory kazań i rozmyślań służące pomocą misjonarzom i kaznodziejom klasztornym"42. Tak dobrze zaopatrzona placówka służyła swoim zasobem w prowadzeniu formacji duchowej bazylianów i duchowieństwa diecezjalnego, a także w uprawianiu

${ }^{36}$ M. Pidłypczak-Majerowicz, Bazylianie w Koronie i Litwie. Szkoty i książki w działalności zakonu, Warszawa 1968, s. 20.

${ }^{37}$ D. Wereda, Z dziejów sanktuarium i placówki oświatowej w Borunach, NP, 105 (2006) s. 201.

${ }^{38}$ Tamże, s. 203.

${ }^{39}$ Tamże, s. 204.

${ }^{40}$ B. Lorens, Bazyliański klasztor św. Onufrego w Ławrowie w XVII-XVIII wieku, NP, 109 (2008) s. 82.

${ }^{41}$ M.Pidłypczak-Majerowicz, BibliotekiklasztorneprowincjikoronnejzakonubazylianówwXVIII wieku, w: Z badań nad polskimi księgozbiorami historycznymi. Studia i materiaty, t. 16, Warszawa 1995, s. 38.

${ }^{42}$ Lorens, Bazyliański klasztor św. Onufrego w Lawrowie, s. 84. 
dydaktyki, kaznodziejstwa, twórczości literacko-naukowej i wszelkiej działalności intelektualnej na ziemi przemyskiej.

W sposób szczegółowy i niezwykle przejrzysty zostały opracowane przez Iwonę Pietrzkiewicz księgozbiory konwentów i szkół kanoników regularnych laterańskich na ziemiach Wielkiego Księstwa Litewskiego. Z zebranego materiału dowiadujemy się, że z kilkudziesięciu siedzib kanoników regularnych na terenie Polski do naszych czasów dotrwał tylko klasztor krakowski i kanonie, które zostały utworzone po 1945 r. Reguły i konstytucje zakonne, dekrety kapituł oraz protokoły wizytacyjne uświadamiają nam, że w klasztorach kanonickich kładziono nacisk na czytelnictwo i działalność pisarską. W poszczególnych konwentach tworzono biblioteki z podobnym księgozbiorem, różniące się zasobnością zbiorów i sposobem przechowywania. Biblioteki kanonickie odznaczały się szczególnym uporządkowaniem według przyjętego schematu, który obowiązywał we wszystkich podległych zgromadzeniach. Zaangażowanie duszpasterskie kanoników i konieczność częstego korzystania ze słowa drukowanego powodowały, że dzieła homiletyczne w znaczący sposób dominowały w bibliotece. Kładziono również nacisk na przygotowanie kaznodziejskie, stąd widoczna różnorodność tematyczna i wydawnicza kazań tak polskich, jak i obcych autorów. Zaopatrzenie bibliotek w klasykę ograniczało się do bardziej znaczących nazwisk takich jak: Cycero, Owidiusz, Seneka, Ezop, Plaut czy Petrarka ${ }^{43}$. Omawiane księgozbiory pod względem językowym są jednolite, gromadzono literaturę w języku polskim, jednak znacząco przeważają zasoby w języku łacińskim. Analizując zawartość klasztorów kanoników na terenie Wielkiego Księstwa Litewskiego należy wspomnieć też o prowadzonych przez nich szkołach i procesie wychowawczym wspieranym przez gromadzone $\mathrm{w}$ bibliotekach współczesne podręczniki szkolne $\mathrm{w}$ języku łacińskim i rosyjskim.

Kontynuując omówienie znaczenia klasztornych bibliotek szkolnych trzeba wspomnieć o galicyjskich żeńskich szkołach klasztornych opisanych przez Bogusławę Czajecką. Programy nauczania do tych szkół były wzorowane na programach szkół austriackich. Wśród licznych przedmiotów wykładanych w szkołach żeńskich można wyróżnić takie grupy jak: filologiczną, historyczno-geograficzną, matematyczną, nauki przyrodnicze, przedmioty artystyczne oraz przedmioty zawodowe ${ }^{44}$. Szkoły klasztorne musiały więc obok dobrze wyposażonych gabinetów specjalistycznych, posiadać dostatecznie dobrze zaopatrzone biblioteki, zawierające dzieła w kilku językach obcych, np.: bogate zbiory sióstr urszulanek, były przeznaczone dla zgromadzenia i nauczycieli, z wyodrębnionym działem dla uczennic. Gromadzono tu dzieła klasyków literatury polskiej i obcej oraz publikacje naukowe potrzebne do wykładania przedmiotów programowych. Każda klasa miała również podręczną bibliotekę do własnej dyspozycji, zaopatrzoną w niezbędne do nauki podręczniki i beletrystykę ${ }^{45}$. Uzupełnieniem całego księgozbioru były czasopisma z których uczennice mogły korzystać w szkolnej czytelni.

${ }^{43}$ I. Pietrzkiewicz, Księgozbiory konwentów i szkół kanoników regularnych laterańskich na ziemiach Wielkiego Księstwa Litewskiego, NP, 92 (1999) s. 491.

${ }^{44}$ B. Czajecka, Szkoły klasztorne żeńskie w Galicji w latach 1867-1914, NP, 61 (1984) s. 264.

${ }^{45}$ Tamże. s. 260. 
Informacje o działalności misjonarzy św. Wincentego a Paulo w parafii Mławskiej przedstawił Leszek Zygner, koncentrując się na zaznajomieniu czytelników z dziejami klasztoru sięgającymi początków XVIII w. Niezwykle ciekawie ujęto działalność szkoły, która w wyniku zawirowań wojennych została reaktywowana przez misjonarzy w XVIII w. Wtedy też w budynku szkolnym obok niezbędnego wyposażenia umieszczono bibliotekę, a w niej ok. 1500 woluminów książek. Nieznane są losy tej kolekcji po kasacie klasztoru. Do dziś zachowało się zaledwie kilka pozycji z tego księgozbioru, a do lat sześćdziesiątych XX w. część księgozbioru misjonarskiego znalazła schronienie w wieży kościoła Świętej Trójcy. Z czasem przechowywane książki uległy zniszczeniu lub zostały skradzione a te, które przetrwały, wraz z księgozbiorem Akcji Katolickiej, przeniesiono do kapitularza, następnie przekazano do biblioteki Seminarium w Płocku ${ }^{46}$.

Zagadnienie klasztornych bibliotek szkolnych, marginalnie przewija się jeszcze w kilku opracowaniach, umieszczonych na łamach Naszej Przeszłości zwłaszcza tam, gdzie jest mowa o działalności szkół, programach nauczania czy podręcznikach szkolnych. Brak w tych tekstach szczegółowych informacji na temat pomieszczeń bibliotecznych, organizacji bibliotek, charakteru kolekcji, sposobu wykorzystania zgromadzonych książek.

W pracy omówiono te materiały, które na łamach „Naszej Przeszłości” jednoznacznie odnoszą się do istnienia i działalności bibliotek klasztornych. Starano się dokonać wnikliwej analizy poszczególnych artykułów czytając uważnie nie tylko te, które wprost dostarczały informacji o badanym problemie. Sprawdzono również i te, w których tylko spodziewano się, że poszukiwane zagadnienie może być opracowane. Na przestrzeni 60 lat w 106 woluminach, życiu monastycznemu i działalności zgromadzeń zakonnych poświęcono wiele kart. Jednak to, co dotyczy bibliotek klasztornych ilościowo prezentuje się dość skromnie. Na uwagę zasługuje jednak jakość tych opracowań i ciężar gatunkowy cytowanych źródeł. Wszystkie omawiane artykuły cechuje niezwykle bogaty aparat naukowy, opierający się na materiałach archiwalnych i dokumentacji źródłowej. Zamieszczone ilustracje i fotografie w sposób rzeczowy uzupełniają przedstawione zagadnienia.

${ }^{46}$ L. Zygner, Działalność misjonarzy św. Wincentego a Paulo w parafii Mławskiej (1712-1864), NP, 84 (1995) s. 151. 


\title{
MONASTIC LIBRARIES IN „OUR PAST”-AN OUTLINE
}

\begin{abstract}
Summary
„Our Past" is a periodical with plenty of interesting monographs, treatises, articles and reviews covering a wide range of issues and problems, which for years had an influence on the culture-forming development of the history of the Church in Poland. Analyzing the thematic content of "Our Past", it can be noticed that in its pages there are a great number of articles on the religious orders and monastic life. The texts often focus on the organizational structure of the monastery, monastic and everyday life. The issue of books and monastic libraries is touched on only marginally. However, the analysed documents reveal that each monastery had at least one small library. Larger monasteries boasted rich collections of books. "Our Past" presents the libraries of the Basilians, Dominicans, Franciscans, Capuchins, Missionary Priests, Benedictines, Cistercians, Canons Regular. It also contains the material on convent libraries, among others, the ones of Bridgettines and female monastic schools. It should be emphasized that the studied articles are characterized by extremely broad scientific apparatus based on archive material and source documentation. Plenty of texts include a rich set of illustrations and photographs, which contributes to the vivid presentation of the mentioned issues.
\end{abstract}

